\title{
Erzya stem-internal vowel-consonant harmony: A new approach
}

\author{
LÁSZLÓ FEJES*
}

Hungarian Research Centre for Linguistics, Budapest, Hungary

Received: December 1, 2020 • Accepted: February 15, 2021

Published online: April 30, 2021

(C) 2021 The Author(s)

\begin{abstract}
Although Erzya harmony is discussed as a kind of vowel harmony traditionally, suffix alternations show that there is a close interaction between consonants and vowels, therefore we should speak about a consonant-vowel harmony. This paper demonstrates that the palatalizedness of the consonants and the frontness of the vowels are also strongly connected inside stems: first syllable front vowels are quite rare after word-initial non-palatalized dentals but are dominant after palatalized ones; first syllable back vowels are dominantly followed by non-palatalized dentals, while the latter are very rare after front vowels.
\end{abstract}

\section{KEYWORDS}

standard Erzya, stem-internal harmony, vowel-consonant harmony, vowel harmony, statistics

The descriptions of Erzya ${ }^{1}$ morphophonology deal with harmony only in suffixation. There is no research made on harmony inside stems. If grammars mention stem-internal harmony Keresztes $(1990,37)$, they just state that there are both harmonic stems (containing either front or back vowels) and "mixed stems" (containing both front and back vowels).

The aim of this paper is to describe the basic tendencies of harmony observable inside Erzya stems. I will concentrate on the role of the consonants in stem internal harmony. In the first section, I will give a short description of Erzya harmony across morpheme boundaries. In the

*Corresponding author. E-mail: fejes@nytud.hu

\footnotetext{
${ }^{1}$ Varieties of Erzya show considerably different systems of harmony (including the complete lack of it). In this paper, the term Erzya always refers to Standard Erzya.
} 
second section, I will describe stem-internal Erzya harmony from various points of view based on dictionary material.

\section{THE NATURE OF ERZYA HARMONY}

Erzya has five vowels: three opaque neutral ones $(/ \mathrm{a} /, / \mathrm{i} /, / \mathrm{u} /)$, which can follow any vowel and are not subject to vowel harmony; and two vowels $(/ \mathrm{o} /, / \mathrm{e} /)$ that usually undergo front/back harmony, i.e. they alternate in suffixes (except for the suffixes with a stable /e/). High vowels are rare in non-initial syllables, and / $\mathrm{u} /$ never occurs in suffixes. Descriptions of Erzya (Bartens 1999, 66-67; Бондарко \& Шолякова 1993, 94-95; Keresztes 1990, 37; Keresztes 2011, 22-23) write about vowel harmony, mentioning that consonants can also play some role in it.

\subsection{The Erzya consonant system}

In Erzya, dental ${ }^{2}$ consonant phonemes can be arranged into non-palatalized vs. palatalized pairs:

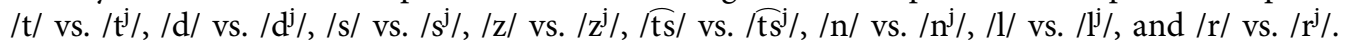

With non-dental consonants, palatalizedness plays no phonological role: however, phonetically they are palatalized in a palatal environment (before front vowels or palatalized dentals or /j/). According to Keresztes (1990, 25) and Keresztes (2011, 18), all consonants other than dentals alternate allophonically, although there are only labial and velar examples given. Bartens $(1999,27)$ states that only labials and velars have palatalized allophones before front vowels. Имайкина $(1996,9)$ claims that the alveolars ${ }^{3} / 3 /, / \mathrm{J} /$ and $/ \mathrm{t} /$ are always "hard", that is, they are never palatalized.

\subsection{Harmony shown in suffix alternation}

Suffix alternations triggered by the stem show that Erzya has a vowel-consonant harmony. Based on Keresztes $(1990,37)$ and Keresztes $(2011,22-23)$, the following suffixation types can be distinguished:

- both triggers and targets are vowels: /kudo-so-nzo/ 'house-INE-3SG' : /vel'e-se-nze/ 'villageINE-S3';

- both triggers and targets are consonants: /kal-t/ 'fish-PL' : /kal $\mathrm{t}^{\mathrm{j}} \mathrm{j} /$ 'willow-PL';

- triggers are vowels and targets are both vowels and consonants: /kudo-vtomo/ 'house-ABE' : /vel'e-vt'eme/ 'village-ABE';

- triggers are consonants and targets are both vowels and consonants: /kal-do/ 'fish-ABL' : $/ \mathrm{kal}^{\mathrm{j}}-\mathrm{d}$ 'e/ 'willow-ABL';

- triggers are vowels but targets are consonants: /kudo-t/ 'house-PL' : /vel ${ }^{\mathrm{j}} \mathrm{e}-\mathrm{t}^{\mathrm{j}} /$ 'village-PL';

\footnotetext{
${ }^{2}$ Phonetically, these consonants are rather post-dental or alveolar, but in the descriptions of Erzya they are traditionally called dental.

${ }^{3}$ Phonetically, these are rather post-alveolars than alveolars. However, I will use the traditional terms for the sake of simplicity: it is easier to distinguish the terms dental and alveolar than alveolar and postalveolar.
} 
- triggers are consonants and targets are vowels: /kal-on' ${ }^{\mathrm{j}}$ ' 'fish-GEN' : /kal $\mathrm{l}^{\mathrm{j}}-\mathrm{en}^{\mathrm{j}}$ / 'willow-GEN' or /kal-so/ 'fish-INE' : /kalj-se/ 'willow-INE'.

Stem-final palatalized consonants and the palatal $/ \mathrm{j} /$ trigger the use of front allomorphs of suffixes alternating in terms of harmony, independently of the quality of the last vowel in the stem. Therefore, Erzya "vowel harmony" should be considered vowel-consonant harmony: independently of whether palatalizedness appears in a vowel or a consonant, it will spread to the following vowels and consonants (until spreading is blocked, see below). Nonetheless, there are some special cases. For stems with a front last vowel and a non-palatalized stem final dental consonant, the palatalization of dentals in the suffix is not triggered, but the fronting of harmonic vowels is: /ver giz-de/ 'wolf-ABL' (cf. /kal-do/ 'fish-ABL' : /kal'-die/ 'willow-ABL').

\subsection{Consonants as targets}

Different consonants may behave differently as targets. As the above examples show, the plosives $/ \mathrm{t} /$ and $/ \mathrm{d} /$ undergo harmony (in a front/palatalized environment, they are replaced by $/ \mathrm{t}^{\mathrm{j}} /$ and $/ \mathrm{d}^{\mathrm{j}} /$, respectively). However, according to the first and last example pairs in the list above, sibilants (and clusters containing them) do not undergo harmony (the same holds for affricates as well). While plosives and sibilants occur in several different suffixes in inflection, none of the other dental consonants do (except for some clusters, in which the other consonant can modify their behaviour).

In derivation, the most productive frequentative suffix, $-/ \mathrm{no} /-:-/ \mathrm{n}^{\mathrm{j}} \mathrm{e} /-$ seems to follow the regularities of harmony, although there are some irregular cases: $/ \operatorname{valgon}^{\mathrm{j}}(\mathrm{ems}) /{ }^{4}$ 'to go down (several times)' (</valg(oms)/ 'to go down'), /jarsn $\mathrm{j}^{\mathrm{j}}(\mathrm{ems}) /$ 'to eat long, to nibble at' (< /jarsa(ms)/ 'to eat'), etc. (the examples come from Mészáros 1986, 91-94). ${ }^{5}$ Another suffix showing $-/ \mathrm{n} /-:-/ \mathrm{n}^{\mathrm{j}} /-$ alternation is the iterative suffix $-/ \mathrm{k} \int \mathrm{no} /-:-/ \mathrm{k} \int \mathrm{n}^{\mathrm{j}} \mathrm{e} /-$, which seems to harmonize with the stem absolutely regularly (Mészáros 1986, 98-100).

With other consonants, the case is even less clear. Mészáros $(1986,100-101)$ discusses the suffix $-/ \mathrm{lda} /-:-/ 1^{\mathrm{j}} \mathrm{d}^{\mathrm{j}} \mathrm{a} /-,-/ \mathrm{ld} /-:-/ \mathrm{j}^{\mathrm{j}} \mathrm{d}^{\mathrm{j}} /-$, which is very rare and improductive. As a deverbal derivational suffix, it seems to be harmonic, but as a denominal suffix only -/ld/- is used, even after front vowels /pizeld(ems)/) 'to be (vividly) green' (</pize/ 'green'), cf. Fejes (2020, 43-44). There is also a suffix -/rda/- : -/rd/- : - $/ \mathrm{r}^{\mathrm{j}} \mathrm{d}^{\mathrm{j}} /$ - (Mészáros 1986, 101-102), but the last one occurs in a single example, $/ \mathrm{s}^{\mathrm{j} u m o r} \mathrm{~d}^{\mathrm{j}}(\mathrm{ems}) /$ 'to be sad', i.e. after a back vowel, which occurs as an alternative to $/ \mathrm{s}^{\mathrm{j} u m o r d}(\mathrm{oms}) /$ 'to be sad'. As a consequence, this suffix alternation cannot be analysed in terms of harmony.

The affricates $/ \widehat{t s} /$ and $/ \mathrm{ts}^{\mathrm{j}} /$ do not occur in suffixes at all. According to Mészáros $(1986,108)$, $\widehat{\mathrm{ts}^{\mathrm{j}}} /$ emerges when a stem-final $/ \mathrm{d}^{\mathrm{j}} /$ and a suffix-initial $/ \mathrm{s} /$ are merged.

Therefore, three groups of dental consonants will be differentiated in the following. The first is the group of stops (both plosives and nasals), which do alternate in suffixes; the second is the

\footnotetext{
${ }^{4}$ The infinitive ending is bracketed. The place of the morpheme boundary can be debated in some cases: for the practice followed here, see 2.1 .

${ }^{5}$ Mészáros also mentions a rare (unproductive) form of the suffix, -/na/-. Unfortunately, she completely ignores the problems related to harmony.
} 
group of approximants, the behaviour of which cannot be examined, since they are not attested in suffixes; and finally, the group of sibilants and affricates, which do not undergo harmony.

\subsection{Approaches to (dis)harmony in Erzya}

Although suffix alternations triggered by the stem show that Erzya has a vowel-consonant harmony - palatalized stem-final dentals trigger fronting of suffix vowels (/kal-so/ 'fish-INE' : $/ \mathrm{kal}^{\mathrm{j}}$-se/ 'willow-INE') and front stem vowels trigger palatalization of suffix-initial dentals (/kudo$\mathrm{t} /$ 'house-PL' : /vel'e- $\mathrm{t}^{\mathrm{j}}$ / 'village-PL') - speaking about stem-internal harmony, the role of dentals is not considered in the literature. For instance, one of Keresztes' examples for stem-internal vowel disharmony (1990, 37), /kos'ke/ 'dry' shows a case when vowel disharmony is probably related to the presence of a palatalized dental.

Only /e/ and /o/ are harmonic vowels, since only they alternate due to harmony. All the other vowels are neutral in the sense that they do not undergo vowel harmony; additionally, they are opaque, that is, they start a new harmonic domain. Back vowels /a/ and /u/ (the latter is rare in non-initial syllables) are opaque neutral vowels in the sense that they appear after any vowel or consonant, but non-palatalized dentals, neutral vowels and /o/ of the harmonic vowels tend to follow them. Similarly, front $/ \mathrm{i} /$ is an opaque neutral vowel in the sense that it can stand after any vowel or consonant, but only neutral vowels and /e/ of the harmonic vowels can follow them (and, in certain circumstances, just palatalized dentals). Considering this, stems like /mazi(j)/ 'beautiful' are not disharmonic in the same sense as /kos'ke/ 'dry', because the latter contains harmonic vowels belonging to different harmonic classes, while the former contains just neutral vowels. Below, I will call (dis)harmony between any (harmonic or neutral) vowels phonetic, and (dis)harmony with a second syllable harmonic vowel phonological. Only phonological disharmony violates the rules of harmony, while phonetic disharmony just means that vowels in the word differ in a feature which plays a role in the vowel harmony of the given language in some circumstances.

\section{STEM-INTERNAL HARMONY}

The aim of this study is to examine stem-internal harmony in Erzya. The research material is based on statistics made on dictionary material of Standard Erzya. From this material, polymorphemic and foreign words had to be removed: problems related to these tasks are described in Sections 2.1.1 and 2.1.2, respectively.

The central research questions are the following: to what extent

- word initial coronals determine the frontness/backness of (harmonic and neutral) vowels (2.2.1);

- vowels of the initial syllable determine the palatalization of consonants following them (2.2.2);

- vowel disharmony is typical for monomorphemic stems (2.2.3);

- intervocalic consonants are responsible for the switch of backness/frontness in phonological harmony (that is, when the second vowel should undergo harmony; 2.2.4): 
The result will show how and in which cases vowel-consonant harmony is active inside stems. All statistical data are based on the material of the Erzya-Hungarian dictionary by Mészáros and Sirmankina (2003), which was based on the Erzya-Russian dictionary by Серебренников, Бузакова \& Мосин (1993).

\subsection{Cleaning of a found object}

Dictionaries do not have monomorphemic headwords exclusively: many of the headwords are derived or compounded. Typical monomorphemic words are mono- or bisyllabic in Erzya; therefore, only words with maximally two syllables will be considered. ${ }^{6}$ The headwords for verbs are the infinitive forms, thus first the infinitive endings were removed before filtering the forms. When the infinitive ends in /-ams/, /a/ belongs to the stem, but when it ends in /-oms/ or /-ems/, /o/ or /e/ may belong to the stem or to the suffix as well (cf. Bartens $(1999,122)$, Mészáros (1998, 33), Pall $(1996,20))$. Since the dictionary does not indicate where /o/ or /e/ before /ms/ in the infinitive form belongs, all these vowels were regarded as part of the suffix, that is, these were ignored during the analysis of the stem. ${ }^{7}$

Five thousand three hundred and twenty five stems were thus selected for further investigation. All the chosen mono- and bisyllabic stems were manually analysed to exclude polymorphemic stems and foreign words (fresh loans from Russian).

2.1.1. Mono- or polymorphemic? There are a lot of verbs etymologically belonging together and derived from the same bound stems (that is, stems not attested in underived forms). These verbs usually show differences in their aspect or valency (causative, reflexive, etc.), e.g. /notskad ${ }^{\mathrm{j}}(\mathrm{ems}) /$ 'to give a pull, to twitch (once)' and /notskaj(ems)/ 'to drag, to pull (repeatedly)', /pidj(ems)/ 'to cook (tr.)' and /pij(ems)/ 'to cook (intr.)', etc. If we counted all these forms, the same stems would be counted several times; if we did not, these patterns would be less represented in the statistics than is reasonable. Therefore, as a compromise, in all similar cases, only one of pairs (or larger groups) of verbs were taken into account. If the related forms represented different patterns, the shorter pattern (having fewer syllables) was chosen, e.g. the latter one from $/ \operatorname{vasod}^{\mathrm{j}}(\mathrm{ems}) /$ and $/ \operatorname{vast}(\mathrm{oms}) /$ 'to meet'. The only exception was when the shorter form was clearly derived (/joms $\mathrm{j}^{\mathrm{j}}(\mathrm{ems}) /$ 'to get lost, to pass, to lapse' contains the widely used reflexive derivational suffix $/ \mathrm{s} \mathrm{j} /$, while $/ \mathrm{joma}(\mathrm{ms}) /$ 'to get lost, to perish, to disappear' does not contain any): in these cases, the longer but unsuffixed verb was taken into account. However, in formally similar cases, when the semantics of the derivational suffix is obscure, the shorter form was taken into account: $/ \mathrm{ker}^{\mathrm{j}} \mathrm{s}^{\mathrm{j}}(\mathrm{ems}) /$ ' to cut' instead of $/ \mathrm{ker}^{\mathrm{j}} \mathrm{a}(\mathrm{ms}) /$ ' id'.

\footnotetext{
${ }^{6}$ Of course, a considerable amount of Erzya stems, such as /alafa/ 'horse' or / $\widehat{t}$ opat $\widehat{t} a /$ 'ghost', are three syllables long. However, it is unlikely that these show a picture considerably different from that of the two syllable words, and their number cannot be so high to make it worth the work of separating them from derived and foreign stems. Anyway, if anyone doubts that, it is enough for them to examine these stems and compare their results with ours.

${ }^{7}$ In some cases, the length of nominal stems is also questionable. For example, /jaks ${ }^{\mathrm{j}} \mathrm{t}^{\mathrm{j}} \mathrm{er}^{\mathrm{j}} \mathrm{e} /$ ' 'red' seems to be three syllables long at first sight, but / $\mathrm{jaks}^{\mathrm{j}} \mathrm{t}^{\mathrm{j}} \mathrm{er}^{\mathrm{j}} \mathrm{d}^{\mathrm{j}}(\mathrm{ems}) /$ 'to be red, to shine red', the verb derived from it, suggests that the stem is just two syllables long and -/e/ is some kind of suffix. Anyway, all the words belonging to such etymons are excluded from our statistics.
} 
The same principles were followed in cases when one (or some) of the derived forms were nouns, e.g. /inks/ 'raker, shave' was taken into account, but /inzed (ems)/ 'to pare' was ignored.

In some cases, slightly different stems show minor differences: /azgond ${ }^{\mathrm{j}}(\mathrm{ems}) /$ 'to bum, to tramp, to roam' : /azgun/ 'bum, vagabond, tramp, roamer'; in these cases, both of the forms were taken into account. However, in a very similar case, /zlidar ${ }^{\mathrm{j}}$ / 'bum, vagabond, tramp, roamer' is a Russian loan (cf. Вершинин (2004-2011, 80)), and /zlid ${ }^{\mathrm{j}} \mathrm{a}(\mathrm{ms})$ / 'to bum, to tramp, to roam' is a verb in a morphologically unclear relation with it. In such cases, both stems were excluded.

Some words seem to be derived, but the supposed base of derivation is not attested. E.g. /azars $\mathrm{j}$ / 'rabid, mad (dog); raving' : *azar(oms)/ 'to rave, to ramp' (cf. /azargad(oms)/ 'to get/go rabid', /azargalj(ems)/ 'to rave, to ramp'). Since these words must be considered non-derived synchronically, and the pattern represented by them is not represented by their base (which does not appear as a separate stem), these were taken into account. However, when these kinds of words seem to form a paradigm, such as /alga/ 'bottom, at bottom, below, under', /aldo/ 'from bottom, from under', /alo/ 'bottom, under (adj.); at bottom, down', /alov/ 'down(wards), under', etc. (which seem to belong to a paradigm of the non-existent */al/ 'bottom, base, downside, underside'), all these forms were ignored, but some forms belonging to the same bound stem in a more obscure way (such as /alka/ 'low; shallow; deep (voice)', /alks/ 'bottom, base, downside, underside; litter; pallet; matress' or /alkuks/ 'really, actually, indeed') were included. A similar principle was followed in cases when the base is used, but its meaning has changed and it got grammaticalized: /ked'ga/ 'at' < 'hand-Prolat', /ked's/ 'to' < 'hand-ILL', /ked 'ste/ 'from' < 'hand-ELA', /ked'se/ 'at' < 'hand-INE', etc. Due to the paradigmatic nature of these forms, they were excluded based on their polymorphemic structures.

In some cases, there was no real morphological difference between two similar forms. When their length was different, only the shorter forms, e.g. /kis/ 'for; because of or /jol/ 'rod, stick', were taken into account, but the longer ones with the same meaning (/kise/ and /jolo/) were excluded. When there was no difference in length, but the choice did not influence the statistics, simply one of the words was ignored, as in the case of $/ \mathrm{ker}^{\mathrm{j}} \mathrm{ez} / \sim / \mathrm{ker}^{\mathrm{j}} \mathrm{ez}^{\mathrm{j}} /$ 'tub, vat' or $/$ lukozd(oms)/ /lukost(oms)/ 'to rock, to swing, to judder (intr.)'. Similarly, when identical forms historically belonging together with two separate meanings were treated as two independent words, such as /a $\mathrm{ft}^{\mathrm{j}}(\mathrm{ems}) /$ 'to stand, to be (located)' and 'to cost' (cf. Russian cmormb 'to stand' and cmoumb 'to cost') and /kolgan/ 'scoop, ladle, dipper' and 'skull' or /tuvor/ 'table' and 'trap', only one of those was taken into account. On the contrary, two identical forms with separate meanings but without any trace of historical link were counted as two words, e.g. /lambavt(oms)/ 'to leaven, to pickle' and /lambavt(oms)/ 'to hang'. Similarly, two alternative forms with some essential difference from our point of view, such as $/ \mathrm{ts}^{\mathrm{j}} \mathrm{ivt}^{\mathrm{j}} \mathrm{ord}(\mathrm{oms}) / \sim \mathrm{ts}^{\mathrm{j}} \mathrm{ivt}^{\mathrm{j}} \mathrm{erd}^{\mathrm{j}}(\mathrm{ems}) /$ 'flash, sparkle, twinkle, etc.', or /is ${ }^{j} \mathrm{ak} / \sim / \mathrm{is}^{\mathrm{j}} \mathrm{en}^{\mathrm{j}} /$ 'yesterday's (adj.)', were taken into account as different words.

When morphological relations were obscure and all the stems represented different patterns, such as in the case of /las ${ }^{j} \mathrm{t}^{\mathrm{j}} \mathrm{e}$ ' 'on a horse', $/ \mathrm{las}^{\mathrm{j}} \mathrm{t}^{\mathrm{j}} \mathrm{a}(\mathrm{ms}) /$ 'to saddle' and /las $\mathrm{s}^{\mathrm{j}} \mathrm{ka}(\mathrm{ms}) /$ 'to trot' or /mejev/ 'angularly; on the back', /mejel'ks/ 'placenta; last child; descendant', /mejonks/ 'back side, inner side' and $/ \mathrm{mej}^{\mathrm{j}} \mathrm{e} /$ 'afterwards, then, later', all the forms were excluded.

These decisions aim to bar out the over- or underrepresentation of certain patterns due to the occurence of the same etymon in words morphologically independent on the synchronic level. However, this goal seems to be unachievable and our individual decisions are certainly debatable. Hopefully, they can at least partially eliminate the random irregularities of the data. Anyway, the data above show that it seems to be impossible to draw a strict boundary between morphologically simple and complex words. 
2.1.2. Foreign or native? It is similarly difficult to divide the lexicon into native and foreign stems. One extreme could be to exclude all the words of foreign origin, including the words inherited from the Finno-Volgaic, Finno-Permic, Finno-Ugric or Uralic protolanguages, but loaned in those times. However, such a restricted material could not reflect the current state of the Erzya language. There are no exact criteria how long ago a word should be loaned to count as native. Therefore, I make use of another approach.

Erzya speakers are bilingual almost without exception: they also speak Russian. However, no other kind of bilingualism is widespread among the Erzya nowadays. As a consequence, when Erzya speakers use Russian loanwords, they are always aware of that (or at least they can say it if they are asked). On the contrary, when they use a word of Tatar or Chuvash origin, they are not aware of that, and they cannot distinguish these words from words inherited from the protolanguges or earlier loans. Moreover, these words are more likely to have undergone a change and could get a more native-like form. Therefore, only words of Russian origin were excluded from the material. ${ }^{8}$

However, not all the words of Russian origin were excluded. Some of them, which have undergone a fundamental change, were kept, e.g. /lavs'a/ 'bench' ( $</$ lavitsa/), /mast ${ }^{\mathrm{j}} \mathrm{a} /$ 'Butter Week' ( $</$ maslienn ${ }^{\mathrm{j} i t s a /)}$, /orta/ 'gate' (</vorota/), /palman'/ 'dimwit' (</bolvan/), etc.

Nonetheless, not all kinds of formal changes were enough to keep the stem. Some Russian words get an extra vowel: /boba/ 'bean' ( $</$ bob/), / $\mathrm{z}^{\mathrm{j}}$ epe/ 'pocket' $\left(</ \mathrm{z}^{\mathrm{j}} \mathrm{ep} /\right)$, /taza/ 'basin, sink, bowl' $(</$ taz/), etc. In some cases, some vowels are adopted due to their realization, not due to their phonological value: /bojka/ 'fluently' $\left(</\right.$ bojko/, [bojkə]). Russian $\mid \overleftarrow{t}_{\varphi} /$ is frequently

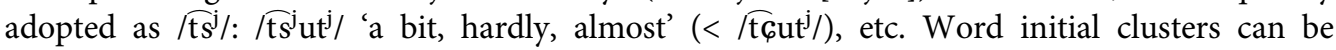
simplified: /nat / 'probably, presumably, certainly' $\left(</ \mathrm{znat}^{\mathrm{j}} /\right)$, etc. These kinds of changes were not enough to keep the stem in the examined material.

The preservation of a stem based on its modified form can be erroneous, since many Russian loanwords of Erzya are borrowed from local dialects, not from the standard language: seemingly modified forms can correspond exactly to a dialectal form. Moreover, it is difficult to be consistent with respect to what kind of change we consider enough to keep a stem. However, as a result of the above procedure, many stems not able to reflect the properties of Erzya stem internal harmony (being formed in another language and having no time to be adapted to Erzya phonology) were excluded.

2.1.3. What remains. The dictionary contained 5,277 items, 1,102 were excluded because they were considered foreign and 2,318 because they were analysed as polymorphemic (the latter group also contained stems derived from foreign elements). As a consequence, 1,857 stems were analysed.

\subsection{Statistics on stem internal harmony}

Based on the phenomena observable at the morpheme boundary, we can suggest that if palatalizedness (frontness) occurs somewhere in the word, there is no way back to back vowels. The word pair /kudo-so-nzo/ 'house-INE-3sG' : /velje-se-nze/ 'village-INE-s3' shows that a front

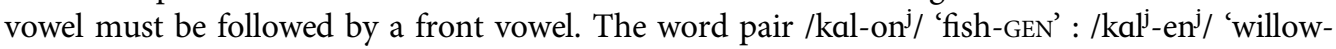
GEN' shows that a palatalized dental is enough to switch from back to front vowels; however, there is no way to switch from front vowels to back ones. The word $/ \mathrm{kal}^{\mathrm{j}} /$ 'willow' demonstrates

${ }^{8}$ Вершинин (2004-2011) was a useful tool in the identification of Russian loans. 
that palatalized dentals can follow back vowels. Therefore, we can suggest that we find a similar tendency stem internally: most of the disharmonic stems with a mid vowel in the second syllable will contain a back vowel in their first and a front vowel in their second syllable, and there must be a palatalized dental consonant between them, which is responsible for the switch.

A simple vowel statistics of the first and second syllables suggest that this can be true. In the first syllable, all the vowels but /a/ take up a very similar proportion, while the number of stems with /a/ is the highest, almost double (Table 1).

If we examine the first syllable vowels of bisyllabic words, we get a similar image (Table 2). Based on the fact that $32 \%$ of the first syllable vowels are front, we must suggest that at least one third of second syllable mid vowels will be front - or even more, due to the palatal dental consonants between the vowels.

The statistics of the second syllable vowels (Table 3) seem to confirm our expectations. High vowels almost disappear, they occur only exceptionally. However, more than half of the second syllable vowels is $/ \mathrm{a} /$. While the proportion of front vowels in the second syllable is less than in the first one, $22 \%$, the proportion of back and front mid vowels is quite close to each other: $45 \%$ of mid vowels are front.

But is it due to the impact of palatalized dental consonants? Can palatal consonants affect vowels inside morpheme boundaries? Can vowels affect the palatalizedness of dental consonants? These are the questions that will be examined in the following sections.

2.2.1. The word initial consonant and the first syllable vowel. The example of $/ \mathrm{kal}^{-o n^{\mathrm{j}} /}$ 'fish-GEN' : / $\mathrm{kal}^{\mathrm{j}}-\mathrm{en}$ / ' 'willow-GEN' shows that the palatalizedness of a dental consonant can cause the frontness of the harmonic vowel at the morpheme boundary. Moreover, we have a suspicion

Table 1. The vowel statistics of the first syllable

\begin{tabular}{|l|c|c|}
\hline Vowel & Stems & Proportion \\
\hline /a/ & 543 & $29 \%$ \\
\hline$/ 0 /$ & 356 & $19 \%$ \\
\hline$/ \mathrm{u} /$ & 318 & $17 \%$ \\
\hline /i/ & 284 & $15 \%$ \\
\hline /e/ & 356 & $19 \%$ \\
\hline
\end{tabular}

Table 2. The vowel statistics of the first syllable in bisyllabic words

\begin{tabular}{|l|c|c|}
\hline Vowel & Stems & Proportion \\
\hline /a/ & 390 & $30 \%$ \\
\hline$/ 0 /$ & 269 & $21 \%$ \\
\hline$/ \mathrm{u} /$ & 229 & $18 \%$ \\
\hline /i/ & 191 & $15 \%$ \\
\hline /e/ & 228 & $17 \%$ \\
\hline
\end{tabular}


Table 3. The vowel statistics of the second syllable in bisyllabic words

\begin{tabular}{|l|c|c|}
\hline Vowel & Stems & Proportion \\
\hline /a/ & 687 & $53 \%$ \\
\hline /o/ & 315 & $24 \%$ \\
\hline /u/ & 22 & $2 \%$ \\
\hline /i/ & 22 & $2 \%$ \\
\hline /e/ & 261 & $20 \%$ \\
\hline
\end{tabular}

that a similar effect can occur between two vowels stem internally. This would mean that non-palatalized consonants and back vowels on the one hand and palatalized consonants and front vowels on the other hand can form domains. But where do those domains begin? Does the (un)palatalizedness of the first consonant determine the backness/frontness of the first vowel, and to what degree, in what cases?

Five groups of consonants will be distinguished:

- hard (non-palatalized dental) with three subgroups:

- stops: /t/, /d/, /n/;

- approximants: /l/, /r/;

- sibilants and an affricate: $/ \mathrm{s} /, / \mathrm{z} /, \widehat{\mathrm{ts}} /$;

- soft (palatalized dental) with three subgroups:

- stops: $/ \mathrm{t}^{\mathrm{j}} /, / \mathrm{d}^{\mathrm{j}} /, / \mathrm{n}^{\mathrm{j}} /$;

- approximants: $/ \mathrm{l}^{\mathrm{j}} /, / \mathrm{r}^{\mathrm{j}} /$;

- sibilants and an affricate: $/ \mathrm{s}^{\mathrm{j}} /, / \mathrm{z}^{\mathrm{j}} /, / \mathrm{ts}^{\mathrm{j}} /$;

- palatal: $/ \mathrm{j} /$;

- alveolar: $/ \mathrm{s} /, / 3 /, / \mathrm{t} \int /$;

- non-coronal: /p/, /b/, /k/, /g/, /f/, /v/, /x/, /m/.

This time labial and velar consonants are not distinguished, because they do not show different behaviour in harmony at the morpheme boundary. They are collapsed into the noncoronal group. However, it is possible that further research can find differences between their distribution.

Two groups of vowels will be distinguished: back (/a/, /o/, /u/) and front (/e/, /i/). Among them, we pay special attention to $/ \mathrm{o} /$ and $/ \mathrm{e} /$, which are affected by palatalizedness at the morpheme boundary, and also to $/ \mathrm{u} /$ and $/ \mathrm{i} /$, which are a potential harmonic pair, but they are very rare in non-first syllables.

Eighty-six words beginning with a consonant cluster were ignored, mainly because a statistically insignificant number of stems belong to each subtype (that is a constructions of consonants belonging to the different classes defined above). Moreover, it is also improbable that consonant clusters show something completely different from what single consonants do.

Statistics on the dental consonants and vowels following them show that front vowels are rather avoided after hard consonants and more preferred after soft consonants: 83\% of the vowels are back after hard consonants and $67 \%$ of the vowels are front after soft 
consonants. The tendency is a bit more noticeable among mid vowels: after hard consonants, $81 \%$ are back, but after soft ones $76 \%$ are front. High vowels are also affected: $71 \%$ of them are back after hard consonants and $78 \%$ of them are front after soft ones.

These numbers suggest that the palatalizedness of the word initial consonant does not automatically trigger the frontness of the vowel following it, rather just supports it. Surprisingly, palatal $/ \mathrm{j} /$, which triggers front vowels at the morpheme boundary, is never followed by a front vowel in the word-intial position. Supposedly, the sequence of a palatal $/ \mathrm{j} /$ and a front vowel is dispreferred in word-initial position because it is difficult to differentiate this sequence from a front vowel in the word-initial position.

All dental consonants behave as triggers at the morpheme boundary, but as we have seen above (1.3), they behave differently as targets: stops undergo harmony, while sibilants and affricates do not; the behaviour of approximants cannot be examined, since they do not occur in regularly alternating suffixes. Unexpectedly, the behaviour of stops on the one hand and sibilants and affricates on the other hand is radically different even word-initially: while hard stops tend to be followed by back vowels and soft stops by front ones, there is no such difference between hard and soft sibilants and affricates. Dental approximants follow a tendency very similar to that of stops.

Interestingly, while soft sibilants and affricates show no clear preference between $/ \mathrm{o} /$ and $/ \mathrm{e} /$, they show stronger preference for $/ \mathrm{i} /$ instead of $/ \mathrm{u} /$. However, the difference between the numbers of mid and high vowels following a soft sibilant or affricate is not significant $(P=0.0759)$.

Alveolar and non-coronal consonants seem to be neutral in this kind of harmony. Although both seem to prefer back vowels (the proportion of them is 70 and $65 \%$, respectively), this is due to the relatively high frequency of the unpaired low /a/. Among mid and high vowels, the proportion of back and front vowels after alveorals and non-coronals is rather balanced: 54 and $45 \%$ of them are back among the mid ones and 58 and 53\% among the high ones, respectively. For comparison, see Fig. 1 and Table 4.

The significance of the data was checked by the online Easy Fisher Exact Test Calculator. ${ }^{9}$ I consider the numbers significant when $P<0.01$, and I consider it as a borderline case when $P<$ 0.05 . The results of the significance test on the differences between different groups of consonants in different positions can be seen in Table 5 .
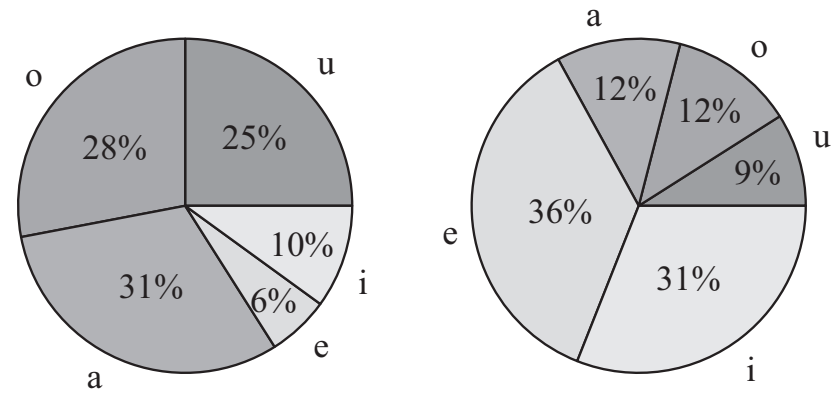

Fig. 1. The proportion of different vowels in the initial syllable following non-palalatized/hard (left) and palatalized/soft (right) dental consonants

${ }^{9}$ https://www.socscistatistics.com/tests/fisher/default2.aspx. 
Table 4. The proportion of back vowels after different kinds of consonants

\begin{tabular}{|l|c|c|c|}
\hline C/V & all & $/ \mathrm{o} / \mathrm{:} / \mathrm{e}$ & $/ \mathrm{u} / \mathrm{:} / \mathrm{i} /$ \\
\hline hard dental & $83 \%(286: 58)$ & $81 \%(96: 22)$ & $71 \%(85: 36)$ \\
\hline soft dental & $33 \%(82: 167)$ & $24 \%(29: 90)$ & $22 \%(22: 77)$ \\
\hline$/ \mathrm{j} /$ & $100 \%(58: 0)$ & $100 \%(21: 0)$ & $100 \%(13: 0)$ \\
\hline hard stop & $93 \%(154: 11)$ & $100 \%(62: 0)$ & $81 \%(48: 11)$ \\
\hline soft stop & $26 \%(18: 53)$ & $19 \%(8: 34)$ & $30 \%(8: 19)$ \\
\hline hard approx. & $93 \%(80: 6)$ & $100 \%(18: 0)$ & $77 \%(20: 6)$ \\
\hline soft approx. & $19 \%(23: 104)$ & $8 \%(3: 33)$ & $5 \%(1: 18)$ \\
\hline hard sib. and affr. & $55 \%(52: 41)$ & $45 \%(16: 22)$ & $47 \%(17: 19)$ \\
\hline soft sib. and affr. & $49 \%(59: 63)$ & $44 \%(18: 23)$ & $25 \%(13: 40)$ \\
\hline alveolar & $70 \%(79: 34)$ & $54 \%(25: 21)$ & $58 \%(18: 13)$ \\
\hline non-coronal & $65 \%(493: 269)$ & $45 \%(132: 162)$ & $53 \%(120: 107)$ \\
\hline
\end{tabular}

Values under $50 \%$ are italicized.

Table 5. The significance of the differences between different groups

\begin{tabular}{|l|c|c|c|}
\hline Contrasted consonants & $\begin{array}{c}\text { Before } \\
\mathbf{V}\end{array}$ & $\begin{array}{c}\text { Before } \\
/ \mathbf{0} / \mathbf{\&} / \mathrm{e} /\end{array}$ & $\begin{array}{c}\text { Before } \\
/ \mathrm{u} / \mathrm{\&} / \mathrm{i} /\end{array}$ \\
\hline hard vs. soft cons. & $<0.01$ & $<0.01$ & $<0.01$ \\
\hline hard vs. soft stops & $<0.01$ & $<0.01$ & $<0.01$ \\
\hline hard vs. soft approx. & $<0.01$ & $<0.01$ & $<0.01$ \\
\hline hard vs. soft sib. and affr. & $(0.335)$ & $(1)$ & 0.0392 \\
\hline hard vs. alveolar cons. & $<0.01$ & $<0.01$ & $(0.2036)$ \\
\hline hard vs. non-coronal cons. & $<0.01$ & $<0.01$ & $<0.01$ \\
\hline soft vs. alveolar cons. & $<0.01$ & $<0.01$ & $<0.01$ \\
\hline soft vs. non-coronal cons. & $<0.01$ & $<0.01$ & $<0.01$ \\
\hline alveolar and non-coronal cons. & $(0.2914)$ & $(0.2667)$ & $(0.7018)$ \\
\hline
\end{tabular}

$P$ in the Fisher Exact Test, italized: borderline case, in brackets: insignificant.

2.2.2. The first syllable vowel and the consonant following it. Examples like /kudo-t/ 'house-PL' : / vel $\mathrm{j}^{\mathrm{j}} \mathrm{e}-\mathrm{t}^{\mathrm{j}} /$ 'village-PL' show that vowels can affect consonants following them. Nonetheless, the example of $/ \mathrm{kal}^{\mathrm{j}}$ / 'willow' shows that palatalized dental consonants can also follow a back vowel, although it is not clear whether they can follow any back vowel or not - 
and if they do, with a similar probability or not. Besides that, the example /ver' giz/ 'wolf shows that front vowels can be followed by non-palatalized dentals.

In this case, the number of consonant clusters is higher: they occur in 664 words at the syllable boundary and in 287 cases word finally. Nonetheless, these cases were ignored, first of all because of the improbability that they could show a picture that is considerably different from what single consonants do. However, it may be worth looking at them closely in the future.

It is clear that hard consonants are preferred after back vowels: $68 \%$ of dentals after first syllable back vowels are non-palatalized, and two individual vowels show similar numbers: /a/: $68 \%$, /o/: $73 \%$ (Table 6). However, the value for $/ \mathrm{u} /, 59 \%$, is surprisingly different and shows no preference of hard consonants. If we take into account the fact that every third dental following a back vowel is palatalized, we have to consider that this kind of preference is not really strong. On the contrary, $88 \%$ of front vowels are followed by soft consonants ( $92 \%$ after /e/ and $81 \%$ after /i/). This means that among the dental consonants following a first syllable front vowel, only every eighth will be hard, which means we speak about a relatively strong tendency - almost three times stronger than the opposite one.

Dental stops and approximants are the consonants which are really sensitive to the frontness of the preceding vowel, especially /e/: a hard consonant belonging to this group occurs only once (/eno/ 'yes, of course'), while five cases after /i/ (/ilik/ 'force, power', /kitord(oms)/ 'to be nervous, excited', /lita(ms)/ 'to ramble, to straggle, to stroll', /pia/ '(parentese) pussy, coot', /ts itord(oms)/ 'sparkle, twinkle'). However, the test shows that the difference between /e/ and /i/ is not significant $(P=0.0554)$.

Approximants turn out to be slightly more sensitive to the preceding vowel word-internally than stops. It is particularly interesting because of their lack in suffixes. As expected, dental sibilants and affricates are not only insensitive to the preceding vowels, but rather they tend to be soft after back and hard after front vowels. However, their number in this position (between the first and second vowel of the word) is considerably low, and the test shows that the numbers are not significant.

From the point of view of the consonants, we find that hard consonants are preceded by back vowels (in $91 \%$ of the cases; $90 \%$ of the mid and $77 \%$ of the high vowels are back). However, we

Table 6. The proportion of hard dental consonants after different vowels

\begin{tabular}{|l|c|c|c|c|}
\hline V/C & Hard (vs. soft) & Stop & Approx. & Sib. and affr. \\
\hline back & $68 \%(208: 100)$ & $70 \%(83: 35)$ & $71 \%(100: 39)$ & $49 \%(25: 26)$ \\
\hline$/$ a/ & $68 \%(95: 44)$ & $74 \%(37: 13)$ & $71 \%(42: 17)$ & $55 \%(16: 13)$ \\
\hline$/ 0 /$ & $73 \%(69: 26)$ & $77 \%(33: 10)$ & $78 \%(31: 9)$ & $42 \%(5: 7)$ \\
\hline /u/ & $59 \%(44: 30)$ & $54 \%(13: 11)$ & $68 \%(27: 13)$ & $40 \%(4: 6)$ \\
\hline front & $12 \%(21: 149)$ & $8 \%(5: 51)$ & $1 \%(1: 74)$ & $62 \%(15: 24)$ \\
\hline$/$ / & $8 \%(8: 93)$ & $3 \%(1: 33)$ & $0 \%(0: 45)$ & $68 \%(7: 15)$ \\
\hline /i/ & $19 \%(13: 56)$ & $18 \%(4: 18)$ & $3 \%(1: 29)$ & $53 \%(8: 9)$ \\
\hline
\end{tabular}

Values under $50 \%$ are italicized. 
find front vowels before soft consonants in just $60 \%$ of the cases: although this relatively low number partially follows from the fact that low vowels are always back, we find moderate numbers in the cases of mid (78\%) and high (65\%) vowels.

Since palatal and alveolar consonants do not undergo palatalization and non-coronal ones do so only allophonically, there is no point examining the combinations with these consonants. For a comparision of dental consonants following first syllable vowels, see Fig. 2 and Table 6.

2.2.3. First and second syllable vowels. One thousand and thirty bisyllabic stems show phonetic vowel harmony, that is, the vowels in them are both back (816) or both front (214). 271 bisyllabic stems are phonetically disharmonic, i.e. one of the vowels is back and the other is front. This means that $79 \%$ of the stems are phonetically harmonic.

Five hundred and two stems are phonologically harmonic, that is, the first syllable back vowel is followed by a back mid vowel $(/ \mathrm{o} /, 296)$, or the first syllable front vowel is followed by a front mid vowel $(/ \mathrm{e} /, 206)$. Seventy four bisyllabic stems are phonologically disharmonic, that is, a back vowel is followed by a second syllable /e/ (55), or a front vowel is followed by a second syllable /o/ (19). Consequently, $13 \%$ of the stems are phonologically disharmonic.

We must conclude that stem internal vowel harmony is quite strong in Erzya in both senses (cf. Fig. 3). We have to add that 177 (65\%) of the 271 phonetically disharmonic stems contain a low vowel (that is, /a/) in the second syllable, where harmony is impossible. In 20 (7\%) of the phonetically disharmonic cases, the second syllable contains a high vowel, which occurs only exceptionally in non-first syllables, and never undergoes harmony in suffixes. High vowels also seem to ignore vowel harmony word internally: after back vowels, /u/ occurs in 15 words and /i/ in 14; after front vowels, /i/ in 8 words and /u/ in 6 words.

2.2.4. The role of consonants in phonological disharmony. Above I have suggested that palatalized consonants must be responsible for many cases of phonological vowel disharmony.

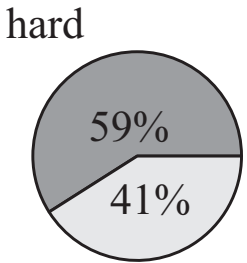

soft

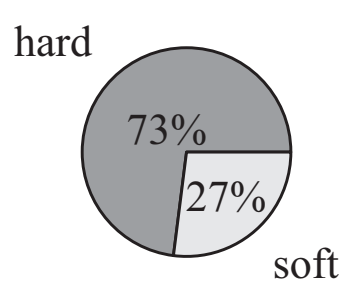

soft

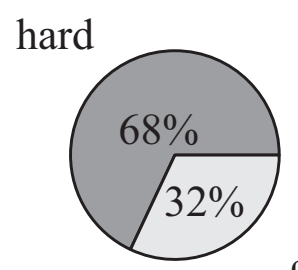

soft

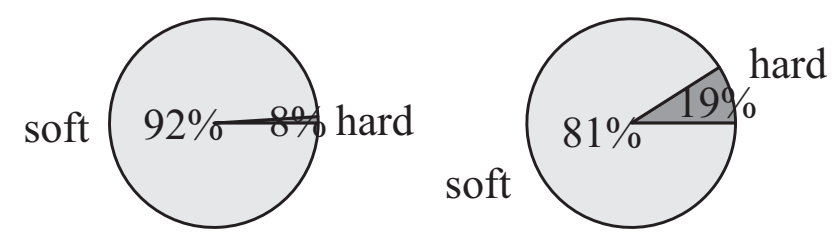

Fig. 2. The proportion of non-palatalized/hard and palatalized/soft dental consonants after different first syllable vowels $(/ \mathrm{u} /$, /o/, /a/; /e/, /i/) 


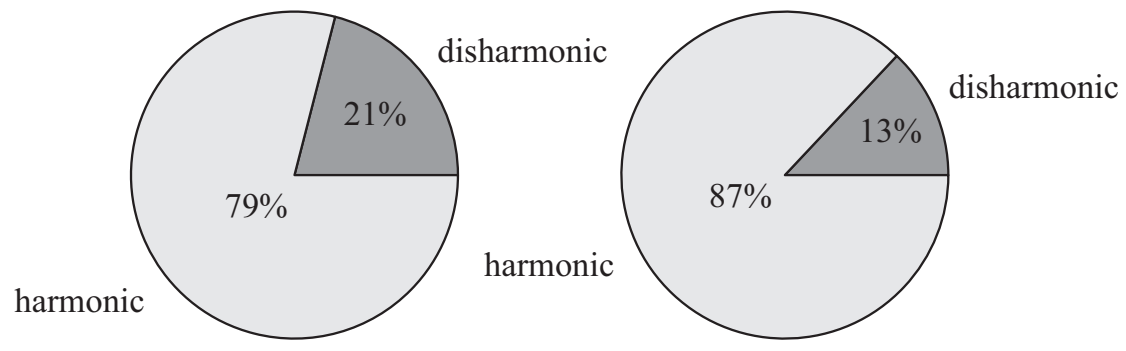

Fig. 3. The proportion of phonetically and phonologically harmonic and disharmonic stems

According to the statistics, there are 55 stems in which first syllable back vowels are followed by a second syllable /e/: in 22 cases there is a soft consonant - palatalized dental or (in 4 cases) /j/ between them, in one case there is a non-coronal (/mokej/ 'one-legged').

All the other cases contain a consonant cluster between the two vowels. Among these, in three cases (/kajs ${ }^{\mathrm{j}} \mathrm{ev}(\mathrm{ems}) /$ 'to become audible, to begin to sound', /pal ${ }^{\mathrm{j}} \mathrm{d}^{\mathrm{j}} \mathrm{ej} /$ 'brother-in-low, husband of a sister', / pol $^{\mathrm{j}} \mathrm{d}^{\mathrm{j}} \mathrm{er}^{\mathrm{j}} /$ ' (onom.), sound of dribble'), we find two soft consonants between the vowels. In ten other cases, a hard consonant is followed by a soft one: however, it is rather just orthography, and both are palatalized, e.g. $/ \mathrm{kanz}^{\mathrm{j}} \mathrm{ed}^{\mathrm{j}}(\mathrm{ems}) /\left(\sim / \mathrm{kanz}^{\mathrm{j}} \mathrm{od}^{\mathrm{j}}(\mathrm{oms}) /\right.$ !) ' to get worn

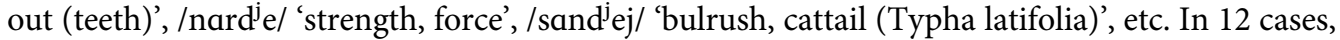
a soft consonant is followed by a non-coronal one, as in the case of the already mentioned /kos'ke/ 'dry'; in half of these cases, the consonant cluster is /jm/, as in /kojme/ 'shovel, spade' or /kujme/ 'basket, hive'. In two cases, an alveolar or a non-coronal consonant is followed by a soft one: /a $\mathrm{ft}^{\mathrm{j}} \mathrm{en} \mathrm{j}^{\mathrm{j} /}$ ' late (at night)', /loks' $\mathrm{j}$ / ' swan'. In one case, a soft consonant is followed by a hard one: $/ \mathrm{t}^{\mathrm{j}} \mathrm{ur}$ 'se/ '(to flow) in torrents'.

However, there are two examples with only hard consonants (/jozne/ 'snake', /parne/ 'colt, foal'), and two with hard consonants and non-dentals (/valske/ 'morning, tomorrow', /t fokfne/ 'evening'). Despite these exceptions, most of the second syllable /e/s following a first syllable back vowel also follow a soft consonant standing between the two vowels. (Although, as the alternation $/ \mathrm{kanz}^{\mathrm{j}} \mathrm{ed}^{\mathrm{j}}(\mathrm{ems}) / \sim / \mathrm{kanz}^{\mathrm{j}} \mathrm{od}(\mathrm{oms}) /$ shows, the switch from back to front vowels is not necessary.)

To sum up, in 50 of the 55 cases when the first syllable back vowel is followed by a second syllable /e/, we find at least one palatalized dental consonant between the vowels. It is in a mere $10 \%$ of the cases that this explanation is not available for the fact that a front mid vowel is found in the second syllable instead of a mid vowel harmonizing with the first syllable back vowel.

There are only 18 cases where first syllable front vowels are followed by second syllable $/ \mathrm{o} /$. In five cases, there is a hard consonant between them: $/ \mathrm{ts}^{\mathrm{j}}$ itord(oms)/ 'sparkle, twinkle', /eno/ 'yes, of course', /kezov/ 'epidemy', /kitord(oms)/ 'to be nervous, excited', /mizold(oms)/ 'to smile'. However, there are also two cases in which a first syllable front vowel is followed by a soft consonant, which is followed by an /o/: /ber'ok/ 'bank, riverside ${ }^{\prime 10}$ and $/ \mathrm{piz}^{\mathrm{j}} \mathrm{ol} /$ 'rowan-berry'. In

\footnotetext{
${ }^{10}$ Without doubt, the word is a Russian loan $\left(/ \mathrm{b}^{\mathrm{j}} \mathrm{er}^{\mathrm{j}} \mathrm{eg} /\right)$, which was not excluded, because its form has considerably changed. Nonetheless, it is possible that Erzya borrowed a dialectal form, which should have been excluded from the material.
} 
two cases, the intervocalic consonants are non-coronal: / $1 \mathrm{j}$ ibord(oms)/ 'to rustle; to fly, to flutter, to flit', /t $\mathrm{t}$ ikor/ 'onomat. (sound of creaking, grating, crumpling)'.

In the remaining 9 cases, we find a cluster intervocally. In 5 cases, they contain at least one non-palatalized dental consonant: /biznovt(oms)/ 'to throw away, to pitch out', /bizmold(oms)/ 'to bustle, to mill, to scrum', /virnovt(oms)/ 'to throw away, to pitch out', /gizmold(oms)/ 'to slip, to slither', /pindold(oms)/ 'to sparkle, to twinkle'. However, in these cases, they contain a palatalized dental (in one case, there is also a form with harmonic vowels): /kir'gov/ 'birchbark',

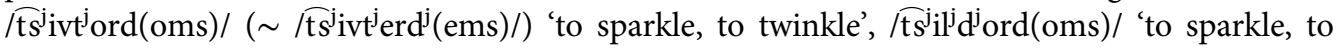
twinkle'. We also find one case when none of the intervocalic consonants is dental (with

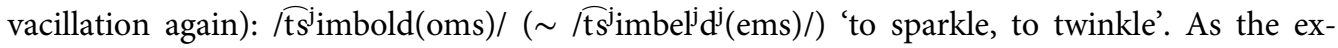
amples show, most of these words are verbs, some of them with similar meanings.

To sum up, in 10 of the 18 cases we find at least one non-palatalized dental consonant between the vowels, in three cases we find at least one palatalized dental consonant and in three cases we find no dental consonants. These numbers suggest that we could hardly explain the disharmony of the vowels with the effect of the intervening consonants. Moreover, at the morpheme boundary, intervening non-palatalized dental consonants do not seem to block the harmony of front vowels (cf. /ver'jiz-de/ 'wolf-ABL' instead of */ver'jiz-do/). Nonetheless, there are marginal cases, when a front stem vowel followed by stem-final non-palatalized dental consonants can be followed by a back /o/ in the suffix: /pizeld(oms)/ ( /pizeld(ems)/) 'to be (vividly) green' ( $</$ pize/ 'green'), /mazild(oms)/ $(\sim /$ mazild(ems)/) 'to be beautiful' $(</$ mazi(j)/ 'beautiful') (Fejes 2020, 43-44).

\section{CONCLUSION}

We have to conclude that a strong tendency for stem-internal harmony is observable in the native vocabulary of Standard Erzya. In this harmony, we discovered interaction both between vowels and between vowels and consonants (in both directions).

- Word initial dentals affect the frontness/backness of vowels (2.2.1): non-palatalized initial dental stops and approximants exclude first syllable /e/ and almost exclude first syllable /i/, and palatalized stops and approximants prefer to be followed by a front vowel. Other consonants practically do not affect the frontness/backness of the vowels following them (although palatal $/ \mathrm{j} /$, which triggers frontness at morpheme boundary, excludes frontness word-initially). This also means that in the first syllable, the retracted allophone of /e/ can be found only after dental sibilants such as in the stems /sed'/ 'bridge' or /zeme/ 'essence, substance, purport; solidity, hardiness' (I could not find any examples with the affricate tts/).

- Vowels of the initial syllable affect the palatalization of dental stops and approximants following them in an unbalanced way (2.2.2): while front vowels /e/ and /i/ almost exclude hard stops and approximants, back vowels allow soft stops and approximants, although they disprefer them to hard ones. However, sibilants and affricates are not affected by the vowels of the initial syllable preceding them.

- Vowel disharmony is untypical for monomorphemic bisyllabic stems (2.2.3). Only approximately every fifth such stem is disharmonic phonetically and every seventh-eighth second syllable mid vowel does not undergo vowel harmony. 
- Intervocalic consonants are responsible for phonological disharmony to a considerable extent (2.2.4). When a vowel /e/ occurs in the second syllable instead of the expected /o/ after a back vowel, in most $(90 \%)$ of the cases a palatalized dental consonant can be found between the two vowels. However, in cases when a vowel /o/ is in the second syllable instead of the expected /e/ after a front vowel, no similar explanation can be applied.

Besides these results, we can add some other observations. Introducing Erzya harmony, we argued that /e/ and /o/ are harmonic vowels (since they undergo harmony), but /i/ and /u/ are not, since they are rare in non-intial syllables and never occur in suffixes as alternating pairs undergoing harmony. Nonetheless, we have seen that in the first syllable they behave similarly not as just triggers (non-palatalized stops and approximants are almost as exceptional after /i/ as after /e/), but also as targets (the distribution of back and front vowels between the mid and high ones is similar after hard and soft stops and approximants in the initial syllables, although mid vowels are slightly more sensitive to the consonant preceding them).

Additionally, since grammars usually do not pay attention to the behaviour of consonants in suffixal harmony, it is generally ignored that dentals can be divided into three groups: the ones that undergo harmony (stops), those which do not (sibilants and affricates), and those which cannot be attested in at least potentionally alternating suffixes (approximants). Our statistics show that this division can be reduced to two groups according to the tendencies of stem internal harmony: stem initial dental stops and approximants behave as triggers, and stops and approximants following the vowel of the initial syllable tend to undergo harmony; while dental sibilants and affricates rather behave as neutral phonemes in both cases.

Finally, we have to add a comment on the nature of the domain. In suffixal harmony, harmonic vowels have to be front if either the vowel preceding them is front or a dental between them and the stem final vowel is palatalized (alternative forms /pizeld(oms)/ 'to be (vividly) green' and /mazild(oms)/ 'to be beautiful' were mentioned as exceptions). Similarly, dental stops and approximants must be palatalized if either a palatalized dental consonant or a front vowel precedes them (although they will not be palatalized if a non-palatalized dental intervenes between them and the preceding front vowel). Based on these, we expect a similar tendency stem internally: likewise, dental stops and approximants are palatalized in almost all the cases after front vowels, although they can be palatalized even after back vowels. However, vowels of the first syllable do not have to be front after word initial palatalized or back after word initial nonpalatalized stops and approximants.

This means that at these three points the nature of the domain is different. In the zone between the initial consonant and the first syllable vowel, there is a balanced tendency for back vowels after hard and front vowels after soft dental consonants. However, in the zone between the first syllable vowel and the consonant following it, non-palatalizedness is allowed only if the preceding vowel is back, and palatalizedness is virtually compulsory if the preceding vowel is front. Finally, at the morpheme boundary, palatalizedness/frontness is compulsory in all the cases when palatalizedness or frontness occurs among the preceding phonemes (despite the blocking effect of the non-palatalized dentals).

As a general conclusion, we must point out that the phenomenon discussed by grammars under the name of vowel harmony in Erzya is rather a complex phenomenon of vowel- 
consonant harmony, which can be attested and functions similarly (although with subtle differences) both in suffixation and stem-internally.

\section{REFERENCES}

Bartens, Raija. 1999. Mordvalaiskielten rakenne ja kehitys. [The structure and the history of the Mordvinic languages]. Helsinki: Suomalais-Ugrilainen Seura.

Fejes, László. 2020. Hunting for antiharmonic stems in Erzya. In Proceedings of the 6th International Workshop on Computational Linguistics of Uralic languages. Wien, Austria, January 10-11, 2020. Stroudsburg, PA: Association for Computational Linguistics. 38-47. https://www.aclweb.org/anthology/ 2020.iwclul-1.6.pdf.

Keresztes, László. 1990. Chrestomathia morduinica. Budapest: Tankönyvkiadó.

Keresztes, László. 2011. Bevezetés a mordvin nyelvészetbe. [An introduction to Mordvinic linguistics].

Debrecen: Debreceni Egyetemi Kiadó.

Mészáros, Edit. 1986. Az erza-mordvin deverbális igeképzők. [Erzya deverbal derivational suffixes]. Nyelvtudományi Közlemények. 88. 89-117.

Mészáros, Edit. 1998. Erza-mordvin nyelvkönyv kezdőknek és haladóknak. [An Erzya coursebook for beginners and advanced students]. Szeged: JATEPress.

Mészáros, Edit and Raisza Sirmankina. 2003. Erza-mordvin-magyar szótár [Erzya-Hungarian dictionary].

Szombathely: Savaria University Press.

Pall, Valdek. 1996. Ersa keel. Õpiku konspekt ja sõnaloend. [The Erzya language. A summary of a coursebook and a vocabulary]. Tallinn: Valdek Pall.

Бондарко, Л. В. and О. Е. Шолякова. 1993. Современные мордовские языки. Фонетика. [The Modern Mordvinic languages. Phonetics]. Саранск: Мордовское книЖное издательство.

Вершинин, Д. В. (еd.). 2004-2011. Этимилогический словарь мордовских (эрзянского и мокшанского) языков. [An etymological dictionary of the Mordvinic (Erzya and Moksha) languages]. Йошкар-Ола: Марийский научно-исследовательный институт языка, литературы и истории им. В. М. Васильева.

Имайкина, М. Д. 1996. Эрзянский язык. Учебное пособие для русскоязычных студентов. [The Erzya language. A tutorial for Russian-speaking students]. В 2 частях. Саранск: Издательство Мордовского Университета.

Серебренников, Б. А., Р. Н. Бузакова and М. В. Мосин. 1993. Эрзянь-рузонь валкс. [Erzya-Russian dictionary]. Москва: «Русский язык».

Open Access. This is an open-access article distributed under the terms of the Creative Commons Attribution 4.0 International License (https://creativecommons.org/licenses/by/4.0/), which permits unrestricted use, distribution, and reproduction in any medium, provided the original author and source are credited, a link to the CC License is provided, and changes - if any - are indicated. (SID_1) 